\title{
Enterotoxin genes, multidrug resistance, and molecular typing of Staphylococcus spp. isolated from organic bovine milk
}

\section{Genes de enterotoxinas, multirresistência a antimicrobianos e caracterização molecular de espécies de Staphylococcus spp. isoladas de leite bovino orgânico}

\author{
Amanda Keller SIQUEIRA ${ }^{1}$; Tatiana SALERNO ${ }^{1}$; Gustavo Henrique Batista LARA ${ }^{1}$; Larissa Anuska Zeni CONDAS ${ }^{1}$; \\ Valéria Cataneli PEREIRA²; Danilo Flávio Moraes RIBOLI², Fernando José Paganini LISTONI ${ }^{1}$; Aristeu Vieira da \\ SILVA $^{3}$, Domingos da Silva LEITE ${ }^{4}$; Maria de Lourdes Ribeiro de Souza da CUNHA²; Márcio Garcia RIBEIRO ${ }^{1}$ \\ ${ }^{1}$ Universidade Estadual Paulista "Júlio de Mesquita Filho", Faculdade de Medicina Veterinária e Zootecnia, \\ Departamento de Higiene Veterinária e Saúde Pública, Botucatu - SP, Brazil \\ ${ }^{2}$ Universidade Estadual Paulista "Júlio de Mesquita Filho", Instituto de Biociências, \\ Departamento de Microbiologia e Imunologia, Botucatu - SP, Brazil \\ ${ }^{3}$ Universidade Estadual de Feira de Santana, Departamento de Ciências Biológicas, Feira de Santana - BA, Brazil \\ ${ }^{4}$ Universidade Estadual de Campinas, Instituto de Biologia, Departamento de Genética, Evolução e Bioagentes, Campinas - SP, Brazil
}

\begin{abstract}
The multidrug resistant and the emergence of methicillin-resistant staphylococci isolated from animals, food, and humans are public health concern. These microorganisms produce different toxins related to food poisoning in humans. This study aimed to characterize Staphylococcus spp. isolated from two organic milk farms in Brazil. A total of 259 milk samples were collected, from which 58 (22.4\%) Staphylococcus spp. were isolated. The highest sensibility to ceftiofur and sulfamethoxazole/trimethoprim was observed in $96.6 \%$ of Staphylococcus spp., and whereas $89 \%$ were resistant to penicillin G. The mecA gene was detected in $13.8 \%$ of the isolates. SEA and SEC were the most common enterotoxins detected. PFGE revealed genetic heterogeneity from $S$. intermedius and $S$. warneri analyzed, while $S$. aureus presented similar profiles among isolates from the two studied herds. To the best of our knowledge, the current study describes for the first time presence of enterotoxins, $m e c A$ gene, and genetic diversity of staphylococci isolated from organic dairy farms in Brazil. Keywords: Organic herd. Multidrug-resistance. mecA. PFGE. CNS.
\end{abstract}

\section{Resumo}

A emergência de estafilococos multirresistentes e resistentes à meticilina, isolados de animais, alimentos e humanos é uma preocupação em saúde pública. Esses micro-organismos produzem diferentes toxinas relacionadas à intoxicação alimentar em humanos. Este estudo caracterizou Staphylococcus spp. isolados em duas fazendas orgânicas no Brasil. Foram coletadas 259 amostras de leite em duas propriedades leiteiras orgânicas, nas quais 58 (22,4\%) estirpes de Staphylococcus spp. foram isoladas. A maior sensibilidade dos isolados foi observada para ceftiofur e sulfametoxazol/trimetoprim em 96,6\%. Em contraste, acima de $89 \%$ de resistência dos estafilicocos foi encontrada para penicilina G. O gene mecA foi identificado em $13,8 \%$ dos isolados. SEA e SEC foram as enterotoxinas mais comumente detectadas. PFGE revelou heterogeneidade genética entre $S$. intermedius e $S$. warneri, enquanto $S$. aureus demonstraram perfis semelhantes entre isolados dos dois rebanhos estudados. Relata-se pela primeira vez no Brasil a detecção de enterotoxinas, o gene mecA e diversidade genética em estafilococos isolados de vacas em produção orgânica.

Palavras-chave: Rebanho orgânico. Multirresistência. mecA. PFGE. SCN.

Correspondence to:

Márcio Garcia Ribeiro

Universidade Estadual Paulista "Júlio de Mesquita Filho",

Faculdade de Medicina Veterinária e Zootecnia, Departamento

de Higiene Veterinária e Saúde Pública

CEP 18618-681, Botucatu, SP, Brazil

E-mail: mgribeiro@fmvz.unesp.br

Received: 06/01/2016

Approved: 11/01/2017
The worldwide demand for organic products, especially dairy products, has increased and the main reasons for that include the consumers' perception regarding the environment in this kind of production, the desire to avoid the use of industrial chemical compounds such as pesticides and antimicrobials, maintenance of animal welfare, and the belief that organic foods are safer and more nutritious (ŚREDNICKA-TOBER et al., 2016). 
In Brazil, despite the exponential increase on dairy consumption, the sector has deficiencies in the production and the quality of raw milk, mainly caused by mastitis and hygiene deficiencies, losing competitiveness in the international market (RIBEIRO et al., 2009). Mastitis in cows is caused predominantly by bacteria, especially Staphylococcus spp. These animals can become reservoirs of resistant microorganisms and spread them by direct or indirect contact (HAMMERUM; HEUER, 2009). Furthermore, some species like Staphylococcus coagulasenegative were frequently found in the milking environment and teat apex (DE VISSCHER et al., 2015) and can also harbor resistance and/or toxin genes, becoming reservoirs of the infectious pathogens.

Antimicrobial resistance is an emerging problem regarding these bacteria isolated from animals and humans. The report of Methicillin-resistant Staphylococcus (MRS) in dairy products and food animals (LEE, 2003) highlight the impact that multidrug-resistant bacteria isolated from cows can generate and the need to develop studies focused on the sensitivity profile of Staphylococcus spp. obtained from animals. In addition, these bacteria were frequently related to food poisoning (CUNHA et al., 2004), as 30 to $50 \%$ of $S$. aureus strains were able to produce these toxins (BALABAN; RASOOLY, 2000).

Because of the paucity of information concerning organic milk in Brazil, the present study aimed at investigating antimicrobial susceptibility, multidrug resistance, the presence of $m e c A$ and enterotoxin genes (sea, seb, sec and sed), and the relation between Staphylococcus spp. isolated from bovine milk from two certified organic dairy farms, farm 1 (SC) and farm 2 (NS), in two cities in the state of São Paulo, Brazil, $300 \mathrm{Km}$ apart from each other. From these farms, 259 individual milk samples were collected between August 2008 and August 2009, in a total of 13 samplings (I XIII) per herd of Holstein and Jersey cows, divided in $15 \mathrm{~mL}$ sterile plastic vials after aseptic preparation of the mammary quarters. Samples were cultivated on defibrinated bovine blood agar (5\%) and MacConkey agar. Plates were incubated aerobically at $37^{\circ} \mathrm{C}$ for 72 hours, with evaluations every 24 hours.

The bacteria were identified based on conventional phenotypic characteristics and according to a modified method (CUNHA et al., 2004) to differentiate coagulasenegative staphylococci (CNS) species. Staphylococcus spp. were submitted to the disc diffusion method (CLSI, 2008,
2012) using antimicrobial agents commercially available and widely recommended in the therapy of bovine mastitis. Oxacillin M.I.C Evaluator Strips ${ }^{\mathrm{a}}(256-0.015 \mu \mathrm{g} / \mathrm{mL})$ were also used to identify methicillin-resistance and the results were interpreted according to Clinical and Laboratory Standards Institute (2012). S. aureus ATCC 33591 (MRSA) and S. aureus ATCC 25923 (susceptible strain) were used as quality controls.

PCR reactions to detect methicillin-resistance gene $(m e c A)$ were performed according Murakami et al. (1991). Enterotoxins genes and tsst-1 gene were detected employing the parameters described by Johnson et al. (1991), with some modifications proposed by Cunha et al. (2006). The reference strains S. aureus ATCC 13565 for sea, S. aureus ATCC 14458 for seb, S. aureus ATCC 19095 for sec, S. aureus ATCC 23235 for sed, and S. aureus ATCC 51650 for tsst-1 were used as positive controls.

A protocol was done by SmaI nuclease digestion followed by PFGE (MCDOUGAL et al., 2003) in order to investigate the relation between Staphylococcus spp. isolated from organic milk.

From 259 milk samples collected from two organic dairy farms (samplings I to XIII), 58 Staphylococcus spp. were identified, 86 samples from farm 1 (SC) and 173 from farm 2 (NS). Forty-eight (82.8\%) of these samples were classified as coagulase-positive staphylococciCPS (S. aureus, S. hyicus, S. intermedius and S. schleiferi coagulans), and $10(17.2 \%)$ as CNS. Three species of CNS (S. capitis urealyticus, S. epidermidis, and S. warneri) were identified using a phenotypic method, but considering that the accuracy of phenotypic tests to identify CNS have been discussed in the last decade, molecular methods were proposed as preferred methods to classify them at species level (DE VISSCHER et al., 2015).

On the one hand, Zadoks and Watts (2009) recommended generalizing as "coagulase-negative Staphylococcus species" especially when only phenotypic methods were applied. On the other hand, De Visscher et al. (2015) did not recommend studying CNS as a single group mainly because of different pathogenicity factors associated to each species and also highlighted the importance of epidemiological studies at the species level to better understand the impact of these bacteria on milk production. The characterization of Staphylococcus spp. based on coagulase test was reliable and did not

\footnotetext{
a M.I.C.E ${ }^{\mathrm{TM}}$. Oxoid.
} 
generate doubts in interpretation. However, although the method used for the definition of CNS at species level is not suitable today, at the time of development of this research we did not have other tools available for that purpose.

The highest in vitro sensibility of the isolates observed was to oxacillin $-88.2 \%$ of the CPS and $87.5 \%$ of the CNS. Penicillin G and ampicillin were the least effective antimicrobials, since $100 \%$ and $62.5 \%$ of the CPS and CNS isolates were resistant to penicillin $\mathrm{G}$, respectively; and
$64.7 \%$ of the CPS were resistant to ampicillin (Table 1). Multidrug resistance to three or more antimicrobials was observed in $15.5 \%$ of the samples. A total of $4 / 58$ (6.9\%) Staphylococcus spp. were classified as MRS by phenotypic methods, two coagulase-positive (S. aureus and S. intermedius) and two CNS (S. epidermidis and S. warneri). The mecA gene was detected in seven CPS, six $S$. intermedius and one $S$. aureus, and in one CNS (S. epidermidis). From these, only $S$. warneri resistant to cefoxitin attested negative to $m e c A$ gene.

Table 1 - In vitro antimicrobial profile of 48 coagulase-positive Staphylococcus spp. and 10 coagulase-negative Staphylococcus spp. isolated from bovine organic milk

\begin{tabular}{|c|c|c|c|c|c|c|c|c|c|c|c|c|c|c|c|c|c|c|c|c|c|}
\hline \multirow{3}{*}{$\begin{array}{l}\text { Organism } \\
\text { Antimicrobial }\end{array}$} & \multicolumn{12}{|c|}{ CPS } & \multicolumn{9}{|c|}{ CNS } \\
\hline & \multicolumn{3}{|c|}{$\begin{array}{l}\text { S. intermedius } \\
\quad(n=27)\end{array}$} & \multicolumn{3}{|c|}{$\begin{array}{c}\text { S. aureus } \\
(n=17)\end{array}$} & \multicolumn{3}{|c|}{$\begin{array}{c}\text { S. schleiferi } \\
\text { coagulans } \\
(\mathrm{n}=3)\end{array}$} & \multicolumn{3}{|c|}{$\begin{array}{c}\text { S. hyicus } \\
(n=1)\end{array}$} & \multicolumn{3}{|c|}{$\begin{array}{l}\text { S. warneri } \\
(n=8)\end{array}$} & \multicolumn{3}{|c|}{$\begin{array}{l}\text { S. epidermidis } \\
(n=1)\end{array}$} & \multicolumn{3}{|c|}{$\begin{array}{l}\text { S. capitis } \\
\text { urealyticus } \\
(\mathrm{n}=1)\end{array}$} \\
\hline & $S(\%)$ & I(\%) & $\mathrm{R}(\%)$ & $\mathrm{S}(\%)$ & I(\%) & $\mathrm{R}(\%)$ & S(\%) & $\mathrm{I}(\%)$ & $\mathrm{R}(\%)$ & $S(\%)$ & l(\%) & $\mathrm{R}(\%)$ & $\mathrm{S}(\%)$ & I(\%) & $R(\%)$ & $\mathrm{S}(\%)$ & l(\%) & $\mathrm{R}(\%)$ & $\mathrm{S}(\%)$ & I(\%) & $R(\%)$ \\
\hline Ampicillin & 11.2 & 18.4 & 70.4 & 23.5 & 11.8 & 64.7 & 66.7 & 0 & 33.3 & 100 & 0 & 0 & 100 & 0 & 0 & 100 & 0 & 0 & 0 & 0 & 100 \\
\hline Ceftiofur & 100 & 0 & 0 & 88.2 & 11.8 & 0 & 66.7 & 33.3 & 0 & 100 & 0 & 0 & 100 & 0 & 0 & 100 & 0 & 0 & 100 & 0 & 0 \\
\hline Enrofloxacin & 55.5 & 33.3 & 11.2 & 94.1 & 5.9 & 0 & 33.3 & 33.3 & 33.3 & 100 & 0 & 0 & 75.0 & 25.0 & 0 & 100 & 0 & 0 & 0 & 100 & 0 \\
\hline Gentamicin & 92.6 & 7.4 & 0 & 94.1 & 0 & 5.9 & 66.7 & 0 & 33.3 & 100 & 0 & 0 & 100 & 0 & 0 & 0 & 0 & 100 & 100 & 0 & 0 \\
\hline Neomycin & 77.9 & 18.4 & 3.7 & 82.4 & 17.6 & 0 & 66.7 & 0 & 33.3 & 100 & 0 & 0 & 100 & 0 & 0 & 0 & 0 & 100 & 100 & 0 & 0 \\
\hline Oxacillin & 96.3 & 0 & 3.7 & 88.2 & 0 & 11.8 & 100 & 0 & 0 & 100 & 0 & 0 & 87.5 & 0 & 12.5 & 0 & 0 & 100 & 100 & 0 & 0 \\
\hline Penicillin G & 0 & 0 & 100 & 0 & 0 & 100 & 0 & 0 & 100 & 100 & 0 & 0 & 37.5 & 0 & 62.5 & 0 & 0 & 100 & 0 & 0 & 100 \\
\hline $\begin{array}{l}\text { Sodium } \\
\text { Cefoperazone }\end{array}$ & 40.8 & 55.5 & 3.7 & 35.4 & 47.0 & 17.6 & 33.3 & 66.7 & 0 & 100 & 0 & 0 & 87.5 & 12.5 & 0 & 0 & 100 & 0 & 0 & 100 & 0 \\
\hline SXT & 96.3 & 0 & 3.7 & 100 & 0 & 0 & 66.7 & 0 & 33.3 & 100 & 0 & 0 & 87.5 & 0 & 12.5 & 100 & 0 & 0 & 100 & 0 & 0 \\
\hline
\end{tabular}

${ }^{*}$ CPS: Coagulase-positive staphylococci; CNS: Coagulase-negative staphylococci. Susceptibility test category, S: sensitive; I: intermediate; R: resistant.

SXT: Trimethoprim/Sulfamethoxazole

The high prevalence of bovine staphylococcal mastitis in Brazil, and the recent introduction of organic procedures in some Brazilian farms probably contribute to the maintenance of multi-resistant Staphylococcus in organic milk system (RIBEIRO et al., 2009). In this scenario, our results from resistance and multidrug-resistance corroborated Walther and Perreten's (2007), and showed that staphylococci collected from cows under organic production may harbor resistant genes, especially in Brazil where the organic dairy production system has been recently established.

In this study it was observed that PCR might be used to detect the mecA gene, since it proved more sensitive $13.8 \%$ of the staphylococci were positive - when compared 
to the phenotypic methods, according to which $6.9 \%$ were positive. Agreeing with Murakami et al. (1991) PCR could be considered the gold standard method in the detection of that gene.

Nevertheless, until now there are few studies involving mecA gene detection of staphylococci isolates from organic milk, particularly in Brazil. In a Swiss report, the authors described methicillin-resistant S. epidermidis isolated from a cow under organic system (WALTHER; PERRETEN, 2007). Coincidentally, in the current study mecA gene associated to phenotypic resistance to oxacillin was identified in one S. epidermidis.
Table 2 shows the results regarding the presence of genes encoding toxins in Staphylococcus spp.. The sea gene was detected in $32.7 \%$ of the staphylococci, seb and sed in 3.4\%, and sec in $39.6 \%$. None of the strains presented tsst-1 gene. Staphylococcal enterotoxins (SE) are responsible for food poisoning around the world (CUNHA et al., 2006) and the isolation of enterotoxigenic Staphylococcus spp. from dairy milk has been reported. Similar to the this study, in Brazil, but under conventional production system, Guimarães et al. (2013) described enterotoxin genes associated with their isolates, $66 \%$ of the CNS and $35 \%$ of the CPS isolated from milk of dairy cows were positive to the enterotoxins genes sea, seb, and sec.

Table 2 - Enterotoxin genes in Staphylococcus spp. isolated from organic dairy milk

\begin{tabular}{|c|c|c|c|c|}
\hline \multirow{2}{*}{ Genes } & *sea & seb & $\mathrm{sec}$ & sed \\
\hline & $\begin{array}{l}\text { n strains/ total } \mathbf{n} \\
\text { of strains (\%) }\end{array}$ & $\begin{array}{c}\text { n strains/ total n } \\
\text { of strains (\%) }\end{array}$ & $\begin{array}{c}\text { n strains/ total n } \\
\text { of strains (\%) }\end{array}$ & $\begin{array}{c}\text { n strains/ total n } \\
\text { of strains (\%) }\end{array}$ \\
\hline \multicolumn{5}{|l|}{ CPS } \\
\hline S. aureus & $5 / 17(29.4)$ & $1 / 17(5.9)$ & $4 / 17(23.5)$ & $1 / 17(5.9)$ \\
\hline S. intermedius & $8 / 27(29.6)$ & $1 / 27(3.7)$ & $13 / 27(48.1)$ & $1 / 27(3.7)$ \\
\hline S. schleiferi coagulans & $1 / 3(33.3)$ & - & $1 / 3(33.3)$ & - \\
\hline S. hyicus & $1 / 1(100.0)$ & - & - & - \\
\hline \multicolumn{5}{|l|}{ CNS } \\
\hline S. warneri & $3 / 8(37.5)$ & - & $4 / 8(50.0)$ & - \\
\hline S. epidermidis & $1 / 1(100.0)$ & - & $1 / 1(100.0)$ & - \\
\hline S. capitis urealyticus & - & - & - & - \\
\hline Total & $19 / 58(32.7)$ & $2 / 58$ & 23/58 (39.6) & $2 / 58(3.4)$ \\
\hline
\end{tabular}

${ }^{*}$ sea: enterotoxin A gene; seb: enterotoxin B gene; sec: enterotoxin C gene; sed: enterotoxin D gene; n: number;

CPS: Coagulase-positive staphylococci; CNS: Coagulase-negative staphylococci

Of the 24 isolates typed by PFGE, ten $S$. intermedius, eight $S$. aureus, and six $S$. warneri were analyzed per group. Three genetic profiles of $S$. intermedius, two of $S$. aureus, and one of $S$. warneri with a coefficient of similarity $\geq 80 \%$ were identified. The PFGE analysis of ten $S$. intermedius revealed the persistence of one pulsotype along one year in the NS herd (PFTI). Other two pulsotypes were observed in the same herd (NS), in different cows (animal numbers 204, 946, 268 and 233) (Figure 1a). Eight $S$. aureus presented two distinct PFGE patterns (PFTI and PFTII) (Figure 1b). One pulsotype (PFTI) formed by four of the six S. warneri evaluated was characterized in one herd (NS) with a three-month interval between samplings (Figure 1c). 
Figure 1 - PFGE profiles from ten Staphylococcus intermedius (1a), eight Staphylococcus aureus (1b) and six Staphylococcus warneri (1c) isolated from bovine organic milk from two farms in Sao Paulo State, Brazil, showing the $80 \%$ similarity line (red line)

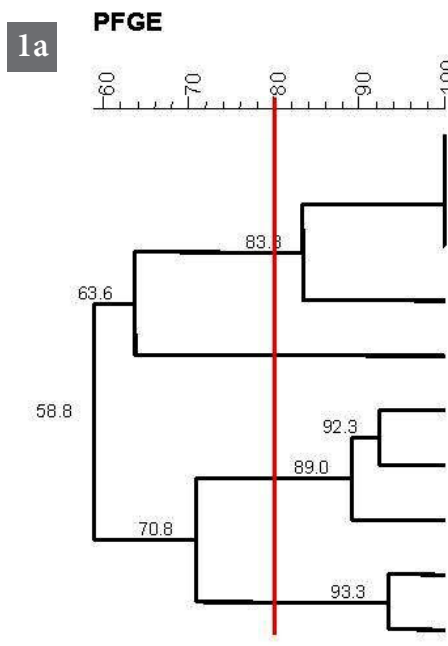

\section{PFGE}

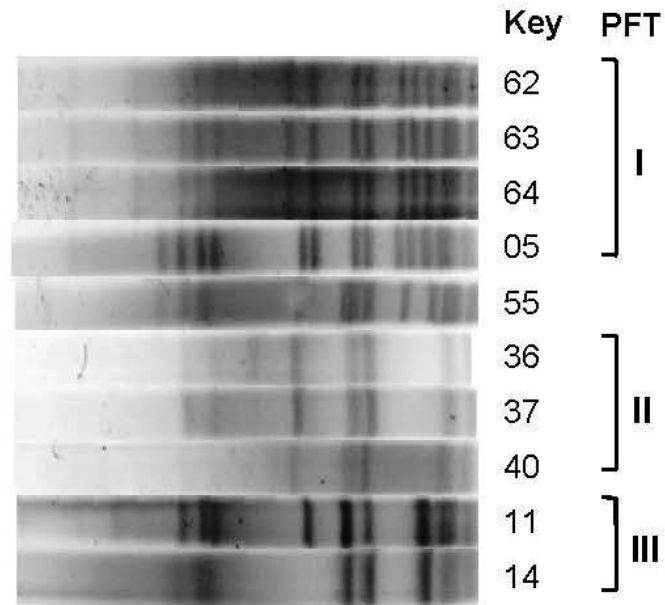

Species

S. intermedius

S. intermedius

S. intermedius

S. intermedius

S. intermedius

S. intermedius

$\mathrm{S}$. intermedius

$\mathrm{S}$. intermedius

S. intermedius

S. intermedius

\section{Collect/Animal}

NSXIII O9AE (204)

NSXIII O9PD (204)

NSXIII O9PE (204)

NS I 05PE (269)

SCXII O3PE

NS VII 03PD (204)

NS VII 03PE (204)

NS VII 2OAE (946)

NSI 11PD (268)

NS I 24 (233)
$1 \mathrm{~b}$

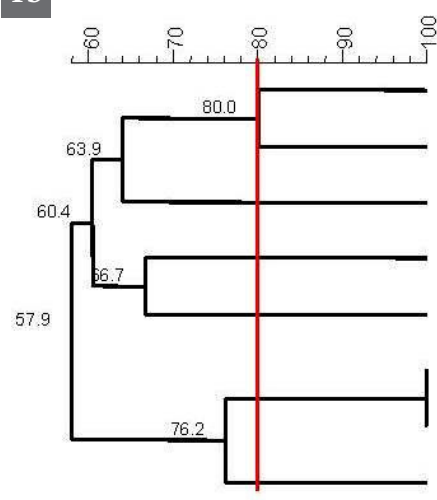

PFGE

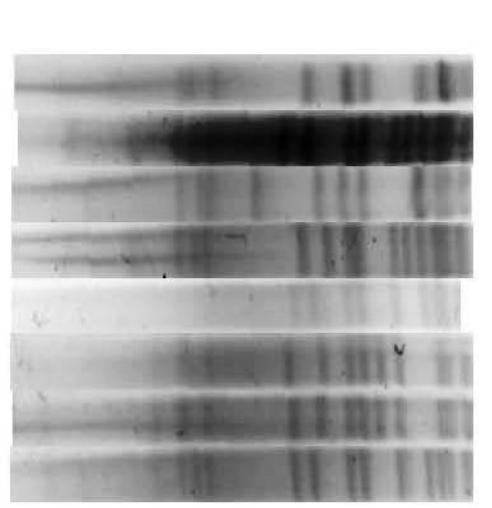

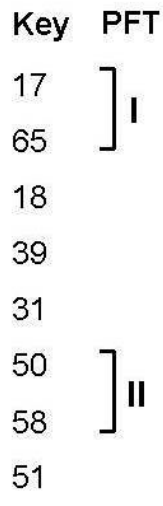

Collect/Animal
SC III 07AE (146)
NSXIII 12PE (110)
SC III 10AD (112)
NS VII 15AE (98)
SC VI 15AD (169)
NSX 22AD (E036)
SCXII 16AE
SCIX 02PD (1 S/N)

1c PFGE

PFGE

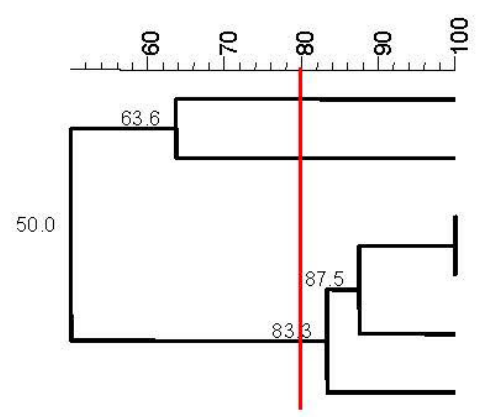

\begin{tabular}{|c|c|c|}
\hline Key & PFT & Species \\
\hline 04 & & S. warner \\
\hline & & S. warner \\
\hline & & S. warner \\
\hline & 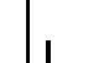 & S. warneri \\
\hline & & S. warner \\
\hline & & S. warner \\
\hline
\end{tabular}

\section{Collect/Animal}

NS I 05AD (269)

NS I 07 (228)

NSXIII 27AE (524)

NSXIII 33PE (025)

NSX 3AE (E040)

NSX 4AE (267)

* PFT: pulsed-field type I to III; NS and SC: names of the two organic dairy herds evaluated; I to XIII: number of samplings; AE/AD/PE/PD: mammary quarters ( $\mathrm{AE}=$ front-left, $\mathrm{AD}=$ front-right, $\mathrm{PE}=$ back-left, $\mathrm{PD}=$ back-right); Inside the parentheses: farm registry number of animals

The persistence of microorganisms in bovine milk may be suspected when the same species is isolated from samples collected consecutively from the same animal (ROBERSON et al., 1996). In fact, our result of PFGE has shown a persistent $S$. intermedius in the farm 2 , as one may see in figure 1a, since this species was also represented by the same digestion pattern. Two S. aureus pulsotypes with more than $80 \%$ of similarity on PFGE were identified in the two organic herds analyzed in this current study. The organic production of bovine milk was the only common fact between the sampled herds. A recent report described that some specific S. aureus 
clones were responsible for cases of bovine mastitis in conventional dairy farms (CASTELANI et al., 2013), although data regarding organic dairy farms were still scarce. We also found a common S. warneri pulsotype being isolated over a three-month period in the same herd. According to another report, CNS can persist in the mammary gland for months (HOSSEINZADEH; SAEI, 2014).

Although more studies with a bigger number of isolates are needed to find out the epidemiology of Staphylococcus spp. in organic production, our results can indicate that there may also be the prevalence of some clones present in this kind of dairy production system. The genotyping of Staphylococcus spp. provided data from the two organic Brazilian dairy farms in order to contribute to start to understand the epidemiology of this pathogen from this kind of dairy system in Brazil.

To the best of our knowledge, the present study describes for the first time in Brazil the presence of enterotoxin genes and mecA in Staphylococcus spp. isolated from organic dairy farms. The resistance of these isolates associated with their toxigenic potential and their genetic diversity highlighted the public health risk involved in the consumption of raw milk and dairy products contaminated with these bacteria.

\section{Acknowledgment}

To Fundação de Amparo à Pesquisa do Estado de São Paulo (Fapesp), São Paulo, Brazil, for the scholarship (grant number 2008/51040-4).

\section{References}

BALABAN, N.; RASOOLY, A. Staphylococcal enterotoxins: a review. International Journal of Food Microbiology, v. 61, n. 1, p. 1-10, 2000. doi: 10.1016/S0168-1605(00)00377-9.

CASTELANI, L.; SANTOS, A. F. S.; MIRANDA, M. S.; ZAFALON, L. F.; POZZI, C. R.; ARCARO, J. R. P. Molecular typing of mastitis-causing Staphylococcus aureus isolated from heifers and cows. International Journal of Molecular Sciences, v. 14, n. 2, p. 4326-4333, 2013. doi: 10.3390/ijms14024326.

CLINICAL AND LABORATORY STANDARDS INSTITUTE. Performance tests for bacteria collected from animals; approved standard - Third Edition. Wayne: CLSI, 2008.

CLINICAL AND LABORATORY STANDARDS INSTITUTE. Methods for dilution antimicrobial susceptibility testing of bacteria that grow aerobically; approved standard - Eight Edition. Wayne: CLSI, 2012.

CUNHA, M. L. R. S.; PERESI, E.; CALSOLARI, R. A. O.; ARAÚJO JÚNIOR, J. P. Detection of enterotoxins genes in coagulase-negative staphylococci isolated from foods. Brazilian Journal of Microbiology, v. 37 , n. 1 , p. $70-74,2006$. doi: 10.1590/S151783822006000100013 .
CUNHA, M. L. R. S.; SENZATO, Y. K.; SILVEIRA, L. V. A. Comparison of methods for the identification of coagulase-negative staphylococci. Memórias do Instituto Oswaldo Cruz, v. 99, n. 8, p. 855860, 2004. doi: http://dx.doi.org/10.1590/S007402762004000800012.

DE VISSCHER, A.; PIEPERS, S.; SUPRÉ, K.; HAESEBROUCK, F.; DE VLIEGHER, S. Short communication: Species group-specific predictors at the cow and quarter level for intramammary infection with coagulase-negative staphylococci in dairy cattle throughout lactation. Journal of Dairy Science, v. 98 , n. 8 , p. $5448-5453$, 2015. doi: $10.3168 /$ jds.2014-9088.

GUIMARÃES, F. F.; NÓBREGA, D. B.; RICHINIPEREIRA, V. B.; MARSON, P. M.; PANTOJA, J. C. F.; LANGONI, H. Enterotoxin genes in coagulasenegative and coagulase-positive staphylococci isolated from bovine milk. Journal of Dairy Science, v. 96, n. 5, p. $2866-2872$, 2013. doi: $10.3168 /$ jds.2012-5864.

HAMMERUM, A. M.; HEUER, O. E. Human Health hazards from antimicrobial resistant Eserrichia coli of animal origin. Clinical Infections and Disease, v. 48, n. 7, p. 916-921, 2009. doi: 10.1086/597292. 
HOSSEINZADEH, S.; SAEI H. D. Staphylococcal species associated with bovine mastitis in North West of Iran: Emerging of coagulase-negative staphylococci. International Journal of Veterinary Science and Medicine, v. 2, n. 1, p. 27-34, 2014. doi: 10.1016/j. ijvsm.2014.02.001.

JOHNSON, W. M.; TYLER, S. D.; EWAN, E. P.; ASHTON, F. E.; POLLARD, D. R.; ROZEE, K. R. Detection of genes of enterotoxins, exfoliative toxins, and toxic shock syndrome toxin 1 in the Staphylococcus aureus by the polymerase chain reaction. Journal of Clinical Microbiology, v. 29, v. 3, p. 426-430, 1991.

LEE, J. H. Methicillin (oxacillin) - resistant Staphylococcus aureus strains isolated from major food animals and their potential transmission to humans. Applied and Environmental Microbiology, v. 69, n. 11, p. 6489-6494, 2003. doi: 10.1128/AEM.69.11.6489-6494.2003.

McDOUGAL, L. K.; STEWARD, C. D.; KILLGORE, G. E.; CHAITRAM, J. M.; McALLISTER, S. K.; TENOVER, F. C. Pulsed-field gel electrophoresis typing of oxacillinresistant Staphylococcus aureus isolates from the United States: establishing a national database. Journal of Clinical Microbiology, v. 41, n. 11, p. 5113-5120, 2003. doi: 10.1128/ JCM.41.11.5113-5120.2003.

MURAKAMI, K.; MINAMIDE, K.; WADA, K.; NAKAMURA, E.; TERAOKA, H.; WATANABE, S. Identification of methicillin-resistant strains of staphylococci by polymerase chain reaction. Journal of Clinical Microbiology, v. 29, n. 10, p. 2240-2244, 1991.

RIBEIRO, M. G.; GERALDO, J. S.; LANGONI, H.; LARA, G. H. B.; SIQUEIRA, A. K.; SALERNO, T.;
FERNANDES, M. C. Microrganismos patogênicos, celularidade e resíduos de antimicrobianos no leite produzido no sistema orgânico. Pesquisa Veterinária Brasileira, v. 29, n. 1, p. 52-58, 2009. doi: 10.1590/S0100736X2009000100008.

ROBERSON, J. R.; FOX, L. K.; HANCOCK, D. D.; GAY, J. M.; BESSER, T. E. Prevalence of coagulase-positive staphylococci, other than Staphylococcus aureus, in bovine mastitis. American Journal of Veterinary Research, v. 57, n. 1, p. 54-58, 1996.

ŚREDNICKA-TOBER, D.; BARAŃSKI, M.; SEAL, C.; SANDERSON, R.; BENBROOK, C.; STEINSHAMN, H.; GROMADZKA-OSTROWSKA, J.; REMBIAŁKOWSKA, E.; SKWARŁO-SOŃTA, K.; EYRE, M.; COZZI, G.; LARSEN, M. K.; JORDON, T.; NIGGLI, U.; SAKOWSKI, T.; CALDER, P. C.; BURDGE, G. C.; SOTIRAKI, S.; STEFANAKIS, A.; YOLCU, H.; STERGIADIS, S.; CHATZIDIMITRIOU, E.; BUTLER, G.; STEWART, G.; LEIFERZ, C. Higher PUFA and n-3 PUFA, conjugated linoleic acid, $\alpha$-tocopherol and iron, but lower iodine and selenium concentrations in organic milk: a systematic literature review and meta- and redundancy analyses. British Journal of Nutrition, v. 115, n. 6, p. 1043-1060, 2016. doi: 10.1017/S0007114516000349.

WALTHER, C.; PERRETEN, V. Letter to the editor: Methicillin-resistant Staphylococcus epidermidis in organic milk production. Journal of Dairy Science, v. 90, n. 12, p. 5351, 2007. doi: 10.3168/jds.2007-0547.

ZADOKS, R. N.; WATTS, J. L. Species identification of coagulase-negative staphylococci: Genotyping is superior to phenotyping. Veterinary Microbiology, v. 134, n. 1-2, p. 20-28, 2009. doi: 10.1016/j.vetmic.2008.09.012. 